\title{
种学通极
}

\section{调幅电磁波作用下 $\mathrm{KI}$ 及 $\mathrm{KMnO}_{4}$ 氧化还原反应的新特点*}

\author{
黄卡玛 刘永清 唐敬贤 赵 军 \\ 李明斌赵 翔 韩树鹏 熊国安
}

(四川大学无线电系, 成都 610064)

\section{关键词调幅 电磁波 氧化还原反应 非线性}

人们早已熟知静电场、静磁场对化学反应的作用”, 在光谱分析中人们也知道物质对微波 的谐振吸收, 即微波对物质分子能级的影响. 现在射频电磁波特别是微波对化学反应的作用 正受到人们的关注. 大量的实验证实了微波能显著提高化学反应的速度和改变反应的机制. 特别在生物电磁学实验中人们发现微弱的微波能量也能导致明显的生物效应, 即生物效应的 能量主要来自于生物体内的新陈代谢, 即电磁波影响了新陈代谢过程, 这就是所谓的非热生 物电磁效应. 1992 年 10 月在荷兰的 Breukelen 召开了首届世界微波化学大会, 会议就微波化 学原理, 微波场中的催化反应,微波在无机化学、有机化学、分析化学和生物化学等领域中的 应用进行了厂泛的讨论. 且前人们将微波加速化学反应的机理仅归结为微波对反应物的选择 性加热, 因而对微波化学原理的认识还有待进一步深化.

微波能够改变反应的活化能和指前因子,这一假设已在微波化学原理的初步讨论中由文 献[2] 给出. 但是微波是怎样改变反应的活化能和指前因子的以及相应的实验工作在文献[2] 中未能给出. 然而要深人揭示微波场对化学反应作用的动力学原理, 研究电磁波对反应活化 能和指前因子的影响是最基本的工作.

本文采用熟知的两个氧化还原反应考察了正弦调幅的射频电磁波对反应的作用。实验表 明电磁波确实改变了反应的活化能和指前因子, 而且活化能和指前因子不再是常量而是与温 度有关的量. 同时也发现电磁波不只是可以加速化学反应, 在一定的条件下也可以抑制化学 反应.

\section{1 实验仪器和方法}

本实验采用熟知的 $\mathrm{KI}$ 与 $\mathrm{H}_{2} \mathrm{O}_{2}$ 和 $\mathrm{KMnO}_{4}$ 与 $\mathrm{H}_{2} \mathrm{C}_{2} \mathrm{O}_{4}$ 两个氧化还原反应 ${ }^{[3]}$, 考察调幅电磁波 对它们的作用. 为了便于比较, 我们用对照的方法进行实验, 即对照组不受电磁波照射, 试验 组受电磁波照射.

1994-12-03 收稿, 1995-05-29 收修改稿

*国家自然科学基金资助项目 


\section{1 实验仪器}

实验中的关键设备之一是千兆赫横电磁传输室 (GTEM Cell), 如图 1所示. 当射频信号

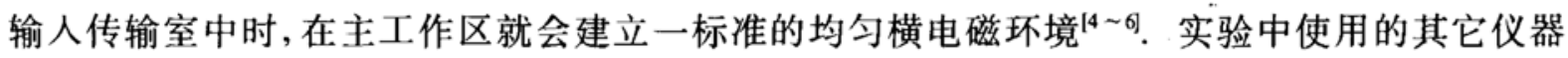

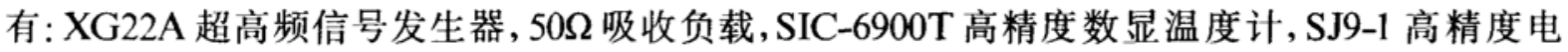
子秒表以及SR37A二踪示波器.

\section{2 实验方法}

实验 1: $\mathrm{KI}$ 与 $\mathrm{H}_{2} \mathrm{O}_{2}$ 的反应

(1) 配制 $A, B, C$ 三种溶液, 其中 $A$ 溶液为 $0.06 \mathrm{~mol} / \mathrm{L} \mathrm{KI}$ 溶 液, $\mathrm{B}$ 溶液为 $2.4 \times 10^{-3} \mathrm{~mol} / \mathrm{L}$ $\mathrm{Na}_{2} \mathrm{~S}_{2} \mathrm{O}_{3}$ 溶液 (含少量可溶性淀粉), $\mathrm{C}$ 溶液为 $16.7 \mathrm{~mL} 6 \mathrm{~mol} / \mathrm{L}$ 醋酸与 $10 \mathrm{~mL} 30 \%$ 过氧化氢混 合稀释成 $500 \mathrm{~mL}$ 溶液.

(2) 将两个 $25 \mathrm{~mL}$ 的烧杯 (标记为 $\mathrm{A}$ 和 $\mathrm{A}^{\prime}$ ) 中 各加人 $10 \mathrm{~mL}$ 的 $\mathrm{A}$ 溶液. 将另两个 $25 \mathrm{~mL}$ 烧杯 (标记为 $\mathrm{B}$ 和 $\mathrm{B}^{\prime}$ ) 中各加人 $10 \mathrm{~mL}$ 的 $\mathrm{B}$ 溶液. 再取

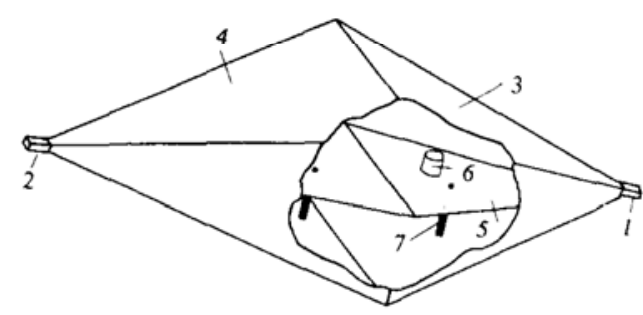

图 1 GTEM Cell

1. 输人过渡器, 2. 输出过渡器, 3,4. 主工作区外 导体, 5. 主工作区内导体, 6. 实验样品, 7. 内导 体支丵棒 两个 $25 \mathrm{~mL}$ 烧杯 (标记为 $\mathrm{C}$ 和 $\mathrm{C}^{\prime}$ ) 各加人 $5 \mathrm{~mL} \mathrm{C}$ 溶液.

(3) 将所有标记烧杯在水浴中加热或冷却 $5 \mathrm{~min}$.

(4) 将标记为 $A$ 和 $B, A^{\prime}$ 和 $B^{\prime}$ 的烧杯中的 $A$ 溶液和 $B$ 溶液混合后再分别与 $C$ 和 $C^{\prime}$ 烧杯中 的 $C$ 溶液混合, 并用秒表测定自 $\mathrm{A}, \mathrm{B}, \mathrm{C}$ 溶液混合时起至溶液全部呈蓝色时所需时间 $\Delta t$, 同时 测定溶液的温度 $T$. 其中 A, B, C 烧杯的混合溶液为对照组, 其反应在 GTEM Cell 外不受电磁 波照射的条件下进行; $A^{\prime}, B^{\prime}, C^{\prime}$ 烧杯的混合溶液在 GTEM Cell 中在电磁波照射下进行反应. GTEM Cell 内的平均功率密度为 $77.35 \mathrm{~W} / \mathrm{m}^{2}$, 电磁波的载波频率为 $130 \mathrm{MHz}$, 正弦调制信号的 频率为 $1 \mathrm{kHz}$, 调制度为 $27 \%$, 溶液的电磁波趋肤深度约为 $0.23 \mathrm{~m}$, 反应溶液的最大测度为 $0.05 \mathrm{~m}$.

实验 2: $\mathrm{KMnO}_{4}$ 与 $\mathrm{H}_{2} \mathrm{C}_{2} \mathrm{O}_{4}$ 的反应

实验步骤与实验 1 相同. 首先配制 $\mathrm{A}, \mathrm{B}, \mathrm{C}$ 三种溶液, 其中 $\mathrm{A}$ 溶液为 $0.02 \mathrm{~mol} / \mathrm{L} \mathrm{KMnO}_{4}$, $B$ 溶液为 $0.5 \mathrm{~mol} / \mathrm{L} \mathrm{H}_{2} \mathrm{C}_{2} \mathrm{O}_{4}, \mathrm{C}$ 溶液为 $0.1 \mathrm{~mol} / \mathrm{L} \mathrm{H}_{2} \mathrm{SO}_{4}$. 然后将上述三种溶液分成两组, 其中 $A(10 \mathrm{~mL}), B(4 \mathrm{~mL}), C(4 \mathrm{~mL})$ 作为对照组用; $A^{\prime}(10 \mathrm{~mL}), B^{\prime}(4 \mathrm{~mL}), C^{\prime}(4 \mathrm{~mL})$ 作为照射组用. 将 它们水浴后分别混合在一起, 并用秒表测定自混合起至溶液变成鲜黄色的时间 $\Delta t$, 同时测定 溶液的温度 $T$. 照射组的反应仍在 GTEM Cell 中在电磁波照射下进行. 电磁波条件与实验 1 相同.

\section{2 结果与讨论}

将实验结果以温度的倒数 $(1 / T)$ 为横坐标, 反应时间倒数的对数 $(\ln (1 / \Delta t))$ 作纵坐标绘 图. $\mathrm{KI}$ 与 $\mathrm{H}_{2} \mathrm{O}_{2}$ 反应的结果如图 2 所示, $\mathrm{KMnO}_{4}$ 与 $\mathrm{H}_{2} \mathrm{C}_{2} \mathrm{O}_{4}$ 反应的结果如图 3 所示.

从图 2 和图 3 可见, 在未加电磁波作用时两个反应的 $\ln (1 / \Delta t)-1 / T$ 关系基本上满足 Arrhenius 方程, 即呈线性关系. 经过线性拟合作出 $\ln (1 / \Delta t)-1 / T$ 直线 (相关系数分别为 -0.993 和 -0.997$)$, 并由此可求得反应的活化能. 由图 2 的直线求得的活化能为 


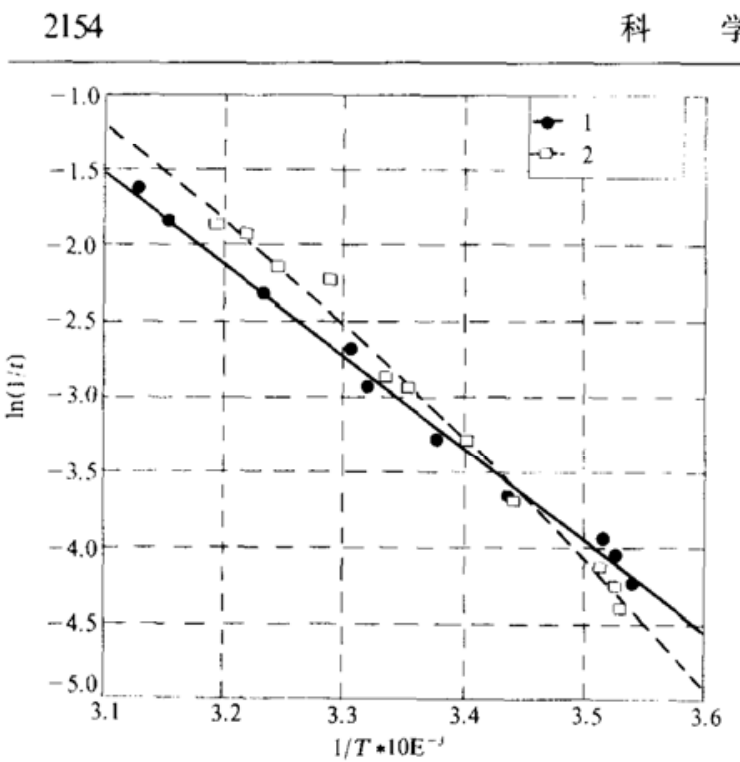

图 $2 \mathrm{KI}$ 与 $\mathrm{H}_{2} \mathrm{O}_{2}$ 反应中 $\ln (1 / \Delta t)$ 与 $1 / T$ 的关系曲线

1 为无电磁波作用的反应, 2 为电磁波作用下的反应

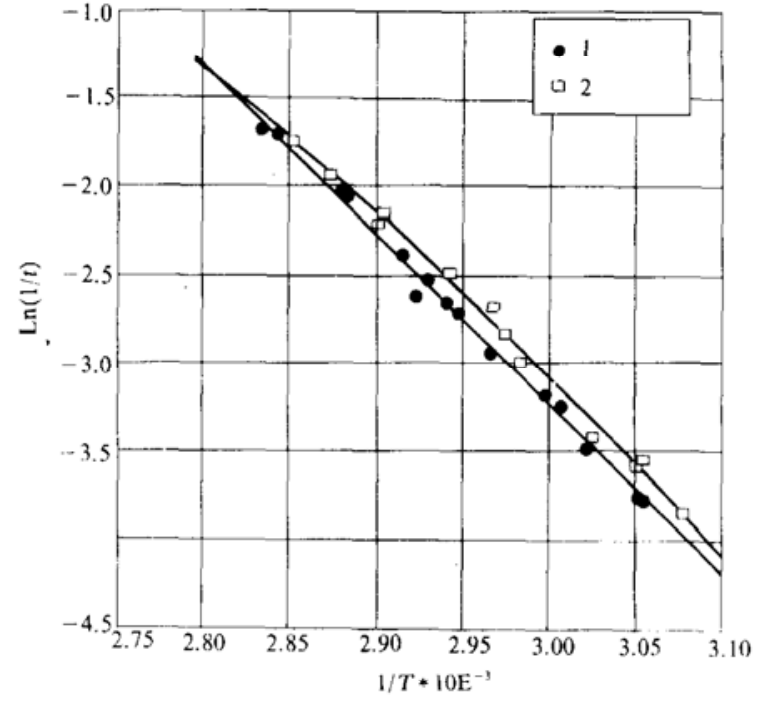

图 $3 \mathrm{KMnO}_{4}$ 与 $\mathrm{H}_{2} \mathrm{C}_{2} \mathrm{O}_{4}$ 反应中 $\ln (1 / \Delta t)$ 与 $1 / T$ 的关系曲线

I 为无电磁波作用的反应, 2 为电磁波作用卜的反应

$$
\Delta E=54.60 \mathrm{~kJ} \cdot \mathrm{mol}^{-1} \text {, }
$$

文献[3] 给出的该实验的活化能为 $58.79 \mathrm{~kJ} \cdot \mathrm{mol}^{-1}$. 由图 3 的直线求得的活化能为

$$
\Delta E=79.08 \mathrm{~kJ} \cdot \mathrm{mol}^{-1} \text {, }
$$

文献[3] 给出的相应实验结果为 $81.59 \mathrm{~kJ} \cdot \mathrm{mol}^{-1}$. 可见本文的实验结果与文献[3] 的实验结果 是基本符合的.

在电磁波作用下的两个反应, 从图 2 和图 3 可以看出, 其 $\ln (1 / \Delta t)-1 / T$ 关系呈明显的非 线性关系. 相应的曲线是经二阶多项式拟合而得的, 其相关系数分别为 -0.998 和 -0.993 . 这 表明, 在电磁波作用下反应的活化能与指前因子皆发生了变化, 而且与温度有关。在 KI 与 $\mathrm{H}_{2} \mathrm{O}_{2}$ 的反应中, 当温度较高时电磁波的作用为加快反应, 当温度较低时电磁波表现出抑制反 应的作用. 在 $\mathrm{KMnO}_{4}$ 与 $\mathrm{H}_{2} \mathrm{C}_{2} \mathrm{O}_{4}$ 的反应中, 在所进行实验的温度范围内, 电磁波均表现为加 快反应的作用, 仅到温度很高时, 才出现抑制反应的趋势。

研究活化能和指前因子的变化是研究电磁波对化学反应作用动力学的基础. 它对于深人 研究微波化学原理以及将电磁波用于化学工业中具有重要的意义; 同时对深人揭示非热生物 电磁效应的机理也将起到推动作用.

\section{参考文献}

1 将和植, 杨建美. 磁场对某些化学反应的影响。化学逆报、1991、36(10): 11 15

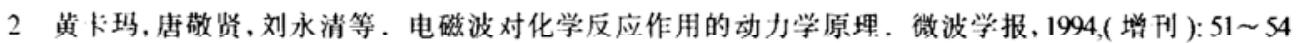

3 办坮四郎, 木村健二郎主编. 朱洪法译. 基础化学实验大全 IV, 物理化学实验. 北京: 科学显及出版社, 1992. 283 285, $279 \sim 281$

4 Huang Kama, Liu Yougqin. A simple method to calculating the distrubution of EM fields in GTEM Cell. IEEF. Trans FMC, 1994, $355 \sim 358$

5 Huang Kama, Lin Weigan, Lin Yuhang. Characteristic impedance of reactangular coaxial cone transmission line. IFF. Proc-Microw Antennas Propag, 1994, 141(4): $21 \sim 24$

6 觉卡玛, 唐敬贤, 刘永清等。一种从直流到超高频的生物电磁学实验系统。生物物理学报, 1994, 10(2): $328 \sim 332$ 